\title{
The Process of Migration and Communication Technology Roles among Labor Migrants in Batam - Indonesia
}

\author{
Inayah Hidayati \\ Research Center for Population, Indonesian Institute of Sciences (LIPI), \\ 12710 Jakarta, Indonesia; inayah.hidayati@lipi.go.id
}

\begin{tabular}{l|}
\hline ARTICLE INFO \\
\hline $\begin{array}{l}\text { Publication Info: } \\
\text { Research Article }\end{array}$
\end{tabular}

How to cite:

Hidayati, I. (2019). The Process of Migration and Communication Technology Roles among Labor Migrants in Batam - Indonesia. Society, 7(2), 173-184.

DOI : 10.33019/society.v7i2.99

Copyright @ 2019. Owned by Author(s), published by Society

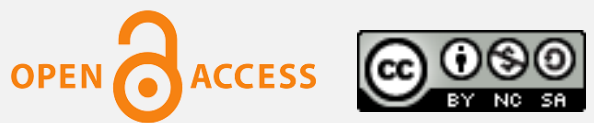

This is an open access article.

License: AttributionNonCommercial-ShareAlike (CC BY-NC-SA)

\begin{abstract}
This research explains the roles of communication technology on the migration process of labor migrants in Batam, Indonesia. Differences between places are strong reasons for people to migrate. The advances in communication technology have freed up opportunities for people to migrate. Technology has made it more accessible for migrants to raise links to their next destination through the internet. Interactions within communication technology make migration easier by decreasing the expenses and risks of moving. The explanations in this research are to understand the communication technology for the migrating process and calculate the social networks of migrants. This research applied mixed methods to explore the migration process with data collected included quantitative data from a survey with 500 respondents and supported by qualitative data from in-depth interviews. The results: 1) Communication technology helps migrants in the migration process, especially for searching for information about the destination area. 2) The migrant who uses communication technology has a strong social network and less risk of migration. The role of communication technology in the migration's processes is as a tool to maintain social ties of migrants, migrant uses their social media to make contact and gain information about their destination. This research related to Sustainable Development Goals (SDG) target number 10.7 which facilitates orderly, safe, regular and responsible migration and mobility of people, including through the implementation of planned and well-managed migration policies, communications technology facilitate safe and wellmanaged migration.
\end{abstract}


Received: October 18, 2019;

Accepted: December 27, 2019;

Published: December 31, 2019;
Keywords: Batam; Communication Technology; Labor; Migrant; Migration; Social Network

\section{Introduction}

Social and economic differences between the two regions are a strong reason for people to migrate. This condition supported by the development of communication technology. Technology makes migration more accessible and opened up an opportunity for people to migrate. Information from communication technology through social media reduces the cost and risk of moving. Social media minimized geographical boundaries from places and sensitized people to move.

Migrants move to a place where they have a connection; this connection sped up by information technology through the internet and social media. In this globalization era, migrants communicate with more modern internet technology. Using these technologies, the migrant will better understand the conditions of their destination. Social media are used to create and establish a long-distance connection.

This paper is to explain the impact of communication technology on the migration process of labor migrants in Batam, Indonesia. Communication technologies can act as a tool and facilitate migration. Migrants use social media to establish a connection with the people in destination areas. Communication technology also determines the selection of migration locations. The social media establish a new relationship between migrants and their next destination, primarily to help in finding accommodations or jobs (Hiller \& Franz, 2004).

Economic factors, including job availability and wage differentials, are among the primary motivations of the population to migrate. This migration flow caused by economic factors was revealed by Todaro (1980) and Harris \& Todaro (1970) who stated that migration developed because of differences in income between regions, especially between urban and rural areas. Migrants from areas that receive lower wages choose various employment opportunities available in other cities and maximize the benefits they get from migrating. Likewise, with labor migration, migrants will constantly come to regions that have attractive factors, including better employment opportunities and wages. Vidyattama's (2014) study shows that differences in wages and types of work have a positive effect on the flow of labor migration in Indonesia.

Batam is one of the objectives of internal migration in Indonesia (Badan Pusat Statistik, 2016) and most of the working age migrant population, namely in the age range of 20-34 years. The migration of working age migrants is motivated by improving their competitiveness. Through migration, they are expected to increase their human capital and competitiveness. In addition to economic reasons, the factors that influence migration are personal motives such as education, career development, returning to the place of origin, to get new experiences (Malamassam et al., 2016). Batam City, as a destination for migration, has answered the expectations of migrant workers in fulfilling their motivation to move.

Batam has become the primary destination for migration because the government's success in developing this city has become an area of the industry, trade, shipbuilding, and tourism. The tidal conditions of Foreign Investment (PMA) and Domestic Investment (PMDN) did not dampen the interest of migrants to find work in Batam City. In fact, according to Indonesia Investment Coordinating Board (BKPM) data in 2016, the value of Foreign Direct Investment (FDI) increased by 46.6 percent (Rp. 4.27 trillion or 63 projects) compared to 2015 . This increase 
in FDI and PMDN attracted more interest in migrants coming to Batam City, which provided thousands of jobs for young people.

\section{Research Methodology}

The explanations in this research are to understand the communication technology for the migrating process and calculate the social networks of migrants. This research used primary data to explore the research questions. The data collection included quantitative data from a survey with 500 respondents and supported by qualitative data from in-depth interviews. The sample selection method used the three-stage Probability Proportional Size (PPS) sampling. The first stage of this sample selection technique was the random selection of districts (five districts). Next, the second stage was carried out to select four villages randomly from the selected sub-districts in the previous stage. In the last stage, respondents were chosen randomly in each selected village. Questionnaires will be filled out if the selected respondents met the criteria for ages 20-34 and the main activity during the past week was work.

\section{Results and Discussion}

\section{A. Batam as a Destination Area for Migrant Worker}

Batam is one of the industrial cities in Indonesia that provides thousands of jobs. This condition makes it the destination of labor migration from all regions in Indonesia. Various job opportunities created by the industry and higher minimum wages of the city are the main attraction for migrant workers to come to Batam.

Labor migration in Batam is the result of rapid economic growth in the decade of the 2000s where investment was massive. The existence of an industrial sector in Batam creates industrybased employment and requires labor-intensive labor. The amount of job needed in Batam requires precise specifications, and residents cannot meet their needs. This creates a large-scale migration to work in the manufacturing industry (Nasution, 2016).

Weak global economic conditions did not discourage prospective migrants from coming to Batam to find work. Not infrequently migrants arriving in Batam do not yet have a clear work destination. The motivation of migrants to go to Batam to work sometimes comes with stories from family or friends who previously worked there.

\section{B. The Motivation of Labor Migrants in Batam}

The survey shows that 69 percent of migrants who come to Batam have the motivation to find work. The rest migrated to this city for reasons of transfer of work location (mutation) and personal reasons such as family reasons. Batam has a very high attraction for job seekers because of the typology of the city as an industrial and trade area. This is in line with the concept of economic push and pulls factors where most people migrate for economic reasons (Fratzscher, 2012). Batam, as a provider of employment, is a pull factor for workers to migrate. The consideration of the availability of jobs and the level of income with migrant-originated areas increasingly make Batam attractive to migrant workers. 
Figure 1

The Motivation of Migrants Moving to Batam ( $\mathrm{N}=500)$

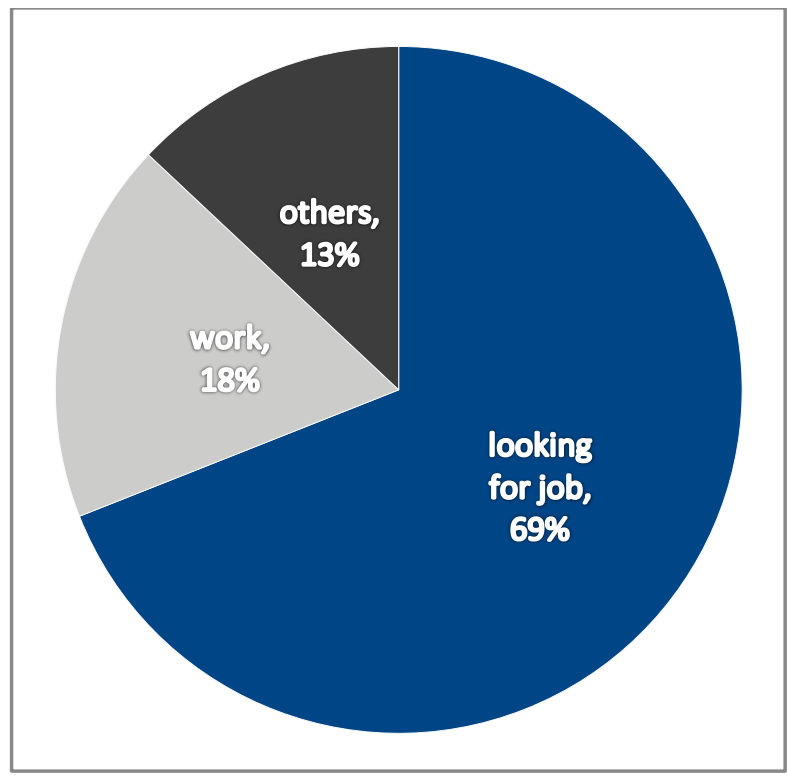

Source: (Survey, 2018)

The results of the Focus Group Discussion (FGD) with labor union and local community associations indicated that Batam was a destination for migration because of the existence of a company that could receive a large number of workers. Many migrants think that if they want to work in a factory, they must migrate to Batam.

"There are many factories in my hometown. I was invited by a friend from Garut to move to Batam. At first, I did not get a job. I am struggling here. Work hard. I tried to register in several factories. Moreover, thank God, I did it. If I am still home, I cannot work at the factory. Many stories in the village, if you want to work, go to Batam". (Community FGD, Batam).

According to the age group, the survey results showed that migrants aged 20-24 years were the largest group that had the motivation to find work in Batam. They are high school graduates who enter the age of job seekers. According to the survey, 79 percent of migrants aged 20-24 years have a senior high school education. This age group is the first-timer workforce who is migrating to Batam. The availability of employment as an operator in the manufacturing industry allows young migrant workers with high school education or below to meet the workforce needs in Batam, Companies in Batam also tend to accept workers who have just graduated from school and without work experience.

"Companies tend to renew their workforce, looking for 'fresh and new', younger, on average 25-30 years. Contract-based, so it is a new average. The old company also had many new contract laborers and recruits. Small companies usually need 'fresh and new' people". (Interview, Badan Perencanaan Pembangunan, Penelitian dan Pengembangan Daerah, Batam). 
Job vacancies in the manufacturing industry shows how easy it is to find a work position in Batam. Migrants can go to Batam without enough capital because of the variety of job availability. Prospective worker sometimes does not need educational requirement.

"My last education is in high school. However, to apply for a job does not require job
qualifications. I used to take training and study on my own. Leaders in the company
teach it. I learned self-taught to do welding". (Labor Union FGD, Batam).

\section{Push and Pull Factors of Migration in Batam}

Migrants in Batam decide to migrate when the place of origin does not have many employment options and naturally, they move to other places that provide many jobs. The difference in economic conditions and the availability of fields that vary from one region to another is one of the triggers of migration flows. Batam is a city that provides employment, has a tremendous pull factor for job seekers. Migrants even attempt to decide to migrate to Batam without obtaining the certainty of getting a job first. According to information from the informant, some of them came to Batam, only friends' invitation and there was no certainty of getting a job.

"I just applied for a job after arriving in Batam. The salary offered is around 2.5 million. I got a job after 2.5 months. I was lucky to have a friend who helped me. Provide a temporary bed. Every day I try to apply for a job at a company in Muka Kuning. I wondered and looked for information. Many friendship networks helped me get a job". (Ar, 29 years old, in-depth interview, Batam).

Based on the results of the survey, 59 percent of job seekers in Batam got jobs after 1-3 months of their arrival day. Job seekers who have difficulty getting a job for up to 4 months by 13.7 percent. The number of companies spread across several industrial zones allows workers to enter work. Short-term contract work systems also facilitate the entry of new workers into a company. The characteristics of jobs that do not require a high level of expertise also further shorten the time of finding work for migrants who have just arrived in Batam.

The condition in Batam shows that the theory of pull factors and drivers of migration from Lee (1966) is still relevant when associated with the phenomenon of labor migration. Lee says that migration occurs because of the different conditions between one region and another. The differences between regions encourage migration flows from ones that have deficiency factors to another that have favorable factors. The difference in cumulative values between the two regions tends to cause migration flows. Lee further explained that the size of migration flows is also influenced by several obstacles, such as costs, transportation, geographical conditions and communication between the two regions. However, the most crucial factor is the individual migration factor, the perception and assessment of the usefulness of the two regions, which in the end will decide to move or settle. 
Table 1

The Reason for Migration to Batam

\begin{tabular}{|l|r|r|}
\hline & Number & Percent \\
\hline Family and marriage & 65 & 13 \\
\hline Education & 5 & 1 \\
\hline Work & 80 & 16 \\
\hline Find a job & 350 & 70 \\
\hline Total & $\mathbf{5 0 0}$ & $\mathbf{1 0 0}$ \\
\hline
\end{tabular}

Source: (Survey, 2018)

In line with Lee's concept, the survey results also reveal the driving factors and attractors of labor migration in Batam. A total of 70 percent of migrants leave their home areas because they are looking for work in Batam. The survey results confirmed that migrants chose to leave their home areas because there was limited employment in their home areas (29.3 percent) covering the type of employment for the number of wages received. Even though the national economic condition tended to slow down in 2017, Batam's city minimum wage (Indonesian: Upah Minimum Kabupaten/Kota or UMK) experienced an increase of 8.71 percent, which was around Rp. 3.5 million. This amount is relatively large when compared to the Kuningan West Java UMK, which is only around 1.4 million Rupiah in the same year. Until now, drinking wages in Batam have indeed become a lucrative attraction for migrant workers, especially those from small cities.

Also, some leave their home areas for entrepreneurship in Batam (2 percent), migrants consider the business opportunity to be higher than their hometown. As an industrial city, Batam requires informal sector businesses such as food stalls, hairdressing salons, and health services, in which entrepreneurs from various regions can enter opportunities. One of the migrants who came from the West Java, move to Batam for opening Sundanese food stall. The decision-making process considers the advantages and disadvantages that will be received.

"I have been in a culinary business in Batam for five years. Batam is a bustling city with many factories. Many employees need food. In the end, I decided to sell Sundanese food. Our food specialties are chicken and fried duck with vegetables. I brought dinner utensils from my hometown so that the food was kept authentic with traditional plates. The plate I brought from home. Traditional dishes from rattan. My chef assistant also from West Java". (Indonesian interview with a migrant from West Java, Batam).

In addition to the push factors, pull factors also influence the flow of labor migration to Batam. Batam, as a particular industrial area, has a wide variety of jobs, both large and medium industries and makes this city a destination for job seekers. Migrants come to Batam in the hope of fulfilling their life needs economically and will ultimately increase their human capital.

Most of the attractive or pull factors of labor to Batam are because the city has a lot of job availability. Besides that, information and the social network factors are also very influential, 
which includes the existence of family and friends in Batam, information on the success of people who have worked in Batam, invited by family or friends to work at the company where they work to higher lure in Batam. The survey results showed that 28.6 percent of migrants chose Batam because there were already family and friends there. 32.8 percent of prospective migrants have obtained job information about the success of the people who have worked there. Other reasons include large salaries (6 percent), invited by friends and friends to work (6 percent), massive entrepreneurial opportunities (1.3 percent) to the choice of Batam because of the strategic and developing location of the city.

\section{Effect of Social Networks on the Dynamics of Labor Migration in Batam}

Social networks are an essential component in the migration process. Social networks formed between former migrants with new migrants and between migrants and local communities (Massey \& Espana, 1987). Previous migrants included family, relatives, and neighbors to friends from their home areas with new migrants. Ideally, social networks formed before migration. The existence of social networks increasingly drives and influences a person's motivation to migrate. The invitation of family and friends from their origin and whereabouts in the destination area is a draw factor for new migrants.

The role of social networks is to help migrants prepare their migration processes, especially in digging up information about destination cities, both before arriving and when they have arrived in Batam. Various types of information related to migration that is important for migrants to know including information on employment opportunities, living costs, accommodation, public facilities, introduction to the area and place of residence, finances to work-related matters. Ideally, the information will come from families, friends and migrant colleagues who have been or are living in Batam and information media, both conventional mass media (newspapers, TV, and magazines) and online media.

Figure 2

With Whom Migrate to Batam? $(\mathrm{N}=500)$

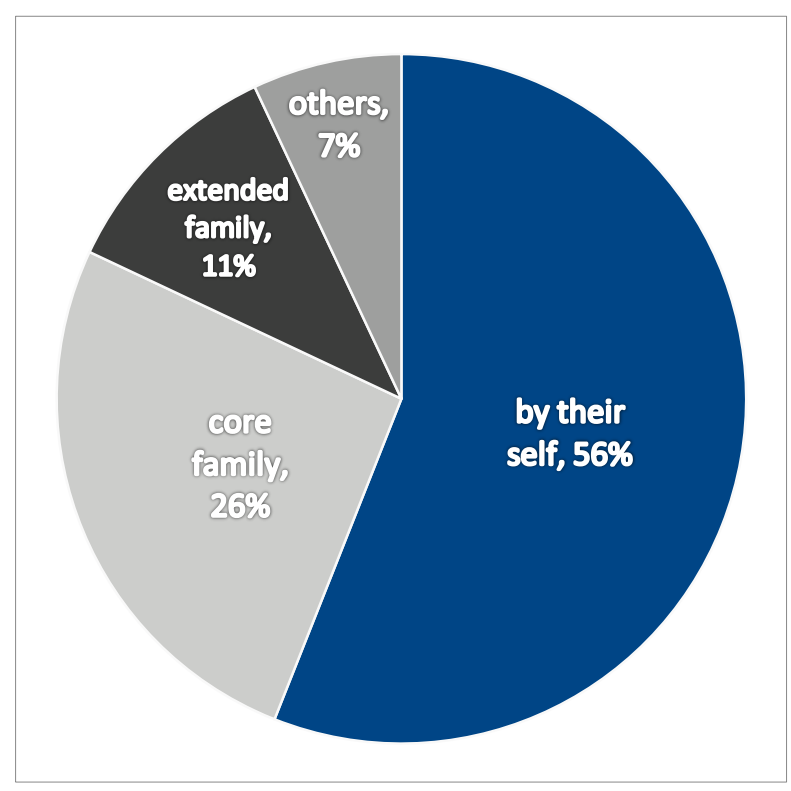

Source: (Survey, 2018)

Copyright $\odot$ 2019. Owned by Author(s), published by Society. This is an open access article under CC-BY-NC-SA License. https://doi.org/10.33019/society.v7i2.99 
The survey revealed that more than half of migrant workers in Batam moved to the city without being accompanied by family or friends. This is because most migrants in Batam are residents aged 2024 years and are not married and migrate for reasons of working or looking for work. Even though migrating without a family member, migrants still have a robust social network with the family they leave behind. More than a quarter of migrants still have the opportunity to return to their hometown at least once a year. Most of the reason is to visit family in the framework of religious holidays.

The existing social networks are expected to encourage job seekers to go to Batam City. Information from colleagues or relatives, especially those who have been successful (getting a job) increasingly triggers migrants to move. With work, new migrants will wrestle with a type of work that is not much different from the network they have. This relates to the information sources that new migrants have from their social networks. This explains why migrants from the same area sometimes dominate specific jobs in a city. The results of the FGD with community groups showed that the selection of workers and colleagues with the same background reason already understood the behavior of the workforce concerned.

Batam is the destination city of migrants from various regions of origin and ethnicity. Each community with ethnic background and place of origin has an association/community whose activities are to strengthen friendship. Each association has a regular agenda for a meeting of its members. (FGD with migrant communities, Batam).

Social networks also play a role in adaptation strategies for migrants in the destination. Previous migrants can act as directors in everything for new migrants. The current migrant can help provide shelter, provide information about areas of residence and work, to help get work. The existence of the ethnic association is also essential when there is ethnic conflict. The head of the association usually acts as a mediator during resolving inter-ethnic conflict. Migrant interactions with the residence and workplace will affect migrant social networks. Most migrants in Batam generally spend their time working. Migrant has limited time for interaction and spending time with colleagues and neighbors around the house where they live. Various forms of social interaction in the destination area are the participation of migrants in social activities in their local areas such as religious-based activities, sports, skills, social gatherings, cooperation, death, and others. When people actively involved in their environment, they will get to know the people around them, and this will facilitate the adaptation of migrants in their new environment. Survey data shows that most migrants participate in "arisan" activities (72\%) in their environment; this formed strong ties of the social networks.

"In a social gathering ("arisan"), we can borrow money for our daily needs. Social gathering is beneficial, especially for residents who live alone. Friendship is everything because we do not have family here". (In-depth interview, Housewife, Batam).

Irfan (2007) and Safitri (2013) in their research divided the functions of social networks into three types: economic, social and information functions. Economic functions include access to assistance in the form of money and goods when migrants need it, especially in the early days in a new residence; economic functions given by relatives or close friends who have already migrated. The next social function is a form of social security and work socialization. Social security includes the availability of shelter and food and assistance from previous migrants, while work socialization is the ins and outs of the work that migrants will do. The last is the function of information, which is to forward all work-related information.

At the beginning of the migration process, migrants generally get the function of social networks from family, friends and online media. The various types of information collected by

Copyright ( 2019. Owned by Author(s), published by Society. This is an open access article under CC-BY-NC-SA License.

https://doi.org/10.33019/society.v7i2.99

180 
migrants will be the provision and also the forms of decision-making that they take. Forms of information obtained include family and friends about job opportunities $(63 \%)$ and information on living costs from online media (74\%). Field observation data and FGDs showed that most migrants in their early days of stay in Batam City received various assistances from relatives and social networks. In fact, in the FGD, the fact was that the kinship-based on ethnicity/background of the place of origin was very strong. One entrepreneur engaged in food (restaurant) has even helped migrants from his home region to work. This brotherhood bond is very close and can be a source of assistance for migrants in need.

\section{E. Migration and Communication Technology}

The differences between regions have become the main reason for migrating. This reinforced by advances in information technology, which are increasingly paving the way to make it easier for residents to move. Technology through social media has made relations between regions of origin and destination areas closer and affordable. Interactions between migrants can be more accessible and minimize the risks and costs of migration.

Nowadays, social media is no longer just a communication tool. Social media has developed into a source of information that can be widely accessed. Social media have strengthened the relationship between two people in two different places from weak ties to strong ties (Haythornthwaite, 2002). Through social media, migrants can still establish relationships with families they leave behind quickly (Mahler, 2001).

The survey shows that migrants in Batam have begun to use social media in their daily lives. More than half have accessed social media for all daily needs such as searching for news, entertainment and social contact $(63.1 \%)$. Batam migrant workers who are dominated by young people have begun to use social media to connect with their social networks. Plentiful information accessed from social media can help migrants make decisions to migrate more carefully. The internet and social media act as providers of information about destinations and media to build social contacts.

One of the facilities increasing the network of migration is communication technology. Advances in technology have given users a chance, in this case, the migrant, to organize and contribute to the data and information in their networks.

There are some uses of social media in facilitating the process of migration. Communication technology makes the process of migration more efficient and inexpensive; the platform of communication technology provides information about the destination area. Instantly, communication technology cuts the distance and time. With its platform, communication technology consolidates the relationship between migrant. Communication technology allows the migrant to create a network with destinations that are rich in sources (Wellman \& Hampton, 1999).

Social media is not just a channel of communication in the network migration, but a virtual infrastructure, sync contacts, and relatively open to facilitate the migration properly. Relationships between users created in the social media network of the migrant can reduce the cost and risk of migration through the exchange of information, resources, and support. The migration network theory assumes that people are going to go to places where they have had contact.

Social media encourage the decision-making process to choose places to work and migrate. All of the informants use communication technology to earn information about the job vacancy and general information about daily life in the destination. To gain more information, they use

Copyright $\odot$ 2019. Owned by Author(s), published by Society. This is an open access article under CC-BY-NC-SA License. 


\section{The Process of Migration and Communication Technology Roles among Labor Migrants in Batam - Indonesia}

Facebook and Whatsapp to making contact with the company and their colleagues in the destination country or place? Participants' comments are proud of these narratives:

"I knew everything about Batam from friends' posts on Facebook." (In-depth interview, $P$, Batam).

There are some uses of Facebook as communication technology in facilitating the process of migration. Communication technology makes its process faster, more efficient, and more modest. Migrants can share information with co-workers and families with communication technology manage to cut the distance geographically. Even the possible migration will be even higher in the future if advances in communication support it through social media.

Contact of the migrant, mostly in destination countries, provides information about the destination and things related to work. This can minimize migrant's fear of their destination countries. They can be preparing themselves for the migration process. Communication technology is a tool to strengthen the connection between them. Social media allow the migrant to build a network with destinations that are rich in resources (Wellman \& Hampton, 1999).

The role of social media in the context of migration is a tool to maintain social ties from migrants. Even with social media is an essential factor in the migration process. According to Dekker \& Engberson (2014), communication channels through social media can facilitate the migration through four functions: strengthening social networks between migrants with families and friends, creating strong ties during migration and integration, creating latent ties and becoming the sources of information and knowledge for migrant candidates.

\section{Conclusion}

The process of globalization will continue to bring significant implications on the upward trend in population mobility. The deletion process of borders often interprets globalization because the world is getting connected and interdependence among regions is increasing. This process occurs as a result of a rapid increase in information technology, communication, and transportation service, which are getting better and affordable. Distribution of migrants in the global era is expanding into many regions (spread across the borders) and migrant communities, in general, form bonds to more than one place (destination and origin) that is sometimes referred to as transnational migrants.

The motivations for migration are affected by the push and pull factors. Push factors always exist at the point of origin and pull factors in the destination. Migration can only occur if the corresponding pull at destination remedies the reason to migrate. Migrant workers in Batam use their social media to gain information before they choose that company to work. They use Facebook and Whatsapp to make contact with their friends and colleagues in the destination country or place.

According to SDGS number 10.7, the government is obliged to facilitate orderly, safe, regular and responsible migration and population mobility, including through the implementation of planned and well-managed migration policies. Perceiving the importance of population migration events in increasing the livelihood up to the economic growth of a country, the government needs to facilitate migrants by providing safe and reliable communication technology channels. The social networks, through the communication technology of migrants, have proven socio-economic implications / socio-economic impacts. Migrants need to establish social relations with family or friends who have experience in the destination. (The conclusion does not represent the idea of the article)

Copyright $($ 2019. Owned by Author(s), published by Society. This is an open access article under CC-BY-NC-SA License. 


\section{Acknowledgement}

This article is a part of the research report by Malamassam, Latifa, Setiawan, Hidayati \& Romdiati (2017) titled 'Optimalisasi Modal Manusia Tenaga Kerja melalui Migrasi: Kasus Kota Batam' and fully funded by the Indonesian Institute of Sciences (Indonesian: Lembaga Ilmu Pengetahuan Indonesia or LIPI).

\section{References}

Badan Pusat Statistik. (2016). Statistik migrasi Indonesia: Hasil survei penduduk antar sensus 2015. Jakarta: BPS.

Bellante, D., \& Jackson, M. (1983). Labor economics: choice in labor markets. McGraw-Hill Companies.

Dekker, R., \& Engbersen, G. (2014). How social media transform migrant networks and facilitate migration. Global Networks, 14(4), 401-418.

Fratzscher, M. (2012). Capital flows, push versus pull factors and the global financial crisis. Journal of International Economics, 88(2), 341-356.

Harris, J. R., \& Todaro, M. P. (1970). Migration, unemployment and development: a two-sector analysis. The American economic review, 60(1), 126-142.

Haythornthwaite, C. (2002). Strong, weak, and latent ties and the impact of new media. The information society, 18(5), 385-401.

Hiller, H. H., \& Franz, T. M. (2004). New ties, old ties and lost ties: the use of the internet in diaspora. New media \& society, 6(6), 731-752.

Irfan, M. 2007. Jaringan sosial dan perkembangan usaha pedagang kaki lima (Studi kasus di kalangan pedagang kaki lima Minangkabau, Pasar Kebon Kembang, Bogor). Skripsi). Bogor: Institut Pertanian Bogor

Lee, E. S. (1966). A Theory of Migration. Demography, 3(1), 47-57.

Mahler, S. J. (2001). Transnational relationships: The struggle to communicate across borders. Identities Global Studies in Culture and Power, 7(4), 583-619.

Massey, D. S., \& España, F. G. (1987). The social process of international migration. Science, 237(4816), 733-738.

Nasution, A. P. (2016). Peran dan Kompetensi Kemampuan Pemerintah terhadap Perkembangan Ekonomi dan Kesejahteraan Masyarakat di Kota Batam. JURNAL DIMENSI, 3(1).

Safitri, Y. M. (2012). Jaringan Sosial dan Strategi Adaptasi Tenaga Kerja Migran Asal Lampung di Desa Jayamukti, Kecamatan Cikarang Pusat, Kabupaten Bekasi, Provinsi Jawa Barat. Skripsi, 5(1).

Todaro, M. (1980). Internal migration in developing countries: a survey. In Population and economic change in developing countries (pp. 361-402). University of Chicago Press.

Vidyattama, Y. (2016). Inter-provincial migration and 1975-2005 regional growth in I ndonesia. Papers in Regional Science, 95, S87-S105.

Wellman, B., \& Hampton, K. (1999). Living networked on and offline. Contemporary Sociology, 28(6), 648-654. 


\begin{abstract}
About the Author
As a researcher, Inayah's main task is to conduct researches which are related to her institution's field expertise. She is working at Research Centre for Population - Indonesian Institute of Sciences (Pusat Penelitian Kepedudukan (P2K) - Lembaga Ilmu Pengetahuan Indonesia (LIPI). P2K LIPI is a government agency which has the main duties in improving the science-development activities through basic and applied research activities, with areas of expertise in the field of demography. Her research interests include population mobility, population policy, family planning, disaster, climate change, and environmental studies.
\end{abstract}

Copyright $($ C 2019. Owned by Author(s), published by Society. This is an open access article under CC-BY-NC-SA License. https://doi.org/10.33019/society.v7i2.99 